\title{
PHYSIOLOGICAL AND BIOCHEMICAL EFFECT OF PYRIPROXYFEN ON INDIAN MEAL MOTH PLODIA INTERPUNCTELLA (HÜBNER) (LEPIDOPTERA: PYRALIDAE)
}

\author{
Aida Ghasemi, Jalal Jalali Sendi*, Mohammad Ghadamyari
}

Department of Plant Protection, University of Guilan, Rasht, Iran

Received: October 10, 2009

Accepted: September 14, 2010

\begin{abstract}
Insect growth regulators generally have a selective effect on the target insects and have practically no apparent side effect on non-target organisms especially vertebrates. Hence, insect growth regulators could be a suitable choice to control pests in stored products. Ten-day-old larvae of Indian meal moth Plodia interpunctella (Hübner) were expressed to the juvenile hormone analogue pyriproxyfen in order to have an effect on growth, metamorphosis, reproduction, lipid and protein contents of ovaries. The larvae were treated by $0.02,0.04,0.08,0.16$, and $0.3 \mathrm{ppm}$ of JHA in an artificial diet where controls received acetone alone. The results indicated significant differences in duration of growth, mean longevity of hatched adults, percentage of emerged normal adults, abnormal pupae, hatched larvae and mean oviposition ratein addition to the lipid and protein of ovaries compared to the controls. An inhibition concentration of fifty $\left(\mathrm{IF}_{50}\right)$ for prevention of emerging adults was recorded $0.134 \mathrm{ppm}$. Pyriproxyfen caused significant defects in the legs and wings of some adults and sever morphological changes in the ovaries of emerged adults. The results showed that pyriproxyfen may be applied as an insecticide to decrease the damage caused by Indian meal moth on stored products. Pyriproxyfen can be used with low side effects to humans.
\end{abstract}

Key words: pyriproxyfen, oviposition, longevity, protein, lipid, Indian meal moth

\section{INTRODUCTION}

Indian meal moth Plodia interpunctella (Hübner) is a cosmopolitan pest of raw stored commodities and of packaged and processed food (Cox and Bell 1991). In recent years, there has been great concern over the toxicity of pesticides on non-target organisms and the environment. Due to such a concern, the use of more specific chemicals on target pests has grown (Paoletti and Pimental 2000). Ordinarily, the control measures in stores are based on fumigation with chemicals like hydrogen phosphate. Residues and insect resistance are reasons for potentially limiting the use of fumigation with chemicals in the near future (World Metrological Organisation 1994). Nowadays, alternative methods are being appreciated. One of the alternatives may be the inclusion of insect growth regulators (IGRs). These compounds are highly effective against various insects attacking stored products and other pests that have become resistant to organic insecticides. Meanwhile, all these compounds are less toxic to mammals and non target organisms because of their non-toxic effect and their quick disintegrating abilities (Carter 1975; Staal 1975; Zurfleuh 1976; Oberlander et al. 1978, 1979; Ishaaya et al. 1987; Ishaaya and Horowitz 1998; Kostyukovsky et al. 2000).

Synthetic IGRs and hormone analogues imitate natural hormones and the physiological processes of insects and are classified as juvenile hormone analogues, ecdysteroid hormones or as ecdysis inhibitors (Mondal and Parween 2000). These compounds are aimed at the physiology and normal growth of the target pests in the juvenile stages. The compounds are meant to reduce adult emergence (Pedigo 2002; Arthur 2003) so that their effect may be more prevalent in the next generation and their sublethal effect may be more pronounced (Rumpf et al. 1998).

IGRs block embryogenesis of insects (Retnakaran 1970; Abdallah et al. 1975), reduce egg production in emerging adults (Metwally et al. 1972) and cause severe morphological disorders (Williams and Amos 1974; Arias and Mulla 1975). Although the prime target site of IGRs (like JH) are endocrine systems there are reports of many physiological and biochemical changes in metabolic pathway caused by these compounds (Kim and Kim 2002; Leonardi et al. 2001).

The juvenile hormone analogue, methoprene, has been reported to affect the growth of ovaries and cause a significant reduction of oocytes when using a topical application (Maiza et al. 2004) on newly emerged adults of Blatta germanica L. (Dictyoptera: Blatellidae). Egg production in Rhyzopertha dominica Fabricius (Coleoptera: Bostrichidae) was significantly reduced by treatment with methoprene and it simultaneously affected egg 
hatchability (Chanbang et al. 2008). Progeny survival was significantly reduced with methoprene in Onthophagus taurus Schreber (Coleoptera: Scarabaeidae) (Nino et al. 2009). Another JHA, hydroprene, is considered to be an alternative to conventional insecticides because of its specific activity against immature insect stages, low persistence in the environment, and nontoxic effect on mammals (Mohandass et al. 2006).

Pyriproxyfen is a pyridine-based juvenile hormone agonist that competes for juvenile hormone binding site receptors in insects, mimicking the action of juvenile hormone and thus maintaining an immature state (Sullivan and Goh 2008). This compound has a relatively low toxicity for mammals and was first registered in Japan in 1991 for controlling public health pests (Miyamoto et al. 1993). The suppression of embryogenesis and adult formation in Bemisia tabaci Gennadius (Heteroptera: Aleyrodidae) (Ishaaya and Horowitz 1992) and Trialeurodes vaporariorum Westwood (Heteroptera: Aleyrodidae) (Ishaaya and Horowitz 1995) was also attributed to pyriproxyfen.

Insect growth regulators generally have a selective effect on the target insects and have almost no apparent side effect on non target organisms especially vertebrates. Hence, they could be a suitable choice to control pests on stored products because of their non or low toxicity to humans. The present study is an extension of previous studies which dealt with the effect of IGRs on stored product insects. Particular attention as paid to sublethal effects aimed at reproduction and its biochemistry.

\section{MATERIALS AND METHODS}

P. interpunctella (Hübner) was collected from infested rice in Rasht, Guilan province, in the northern region of Iran. The insects were reared in rectangular plastic jars $(7.5 \times 145 \times 18.5 \mathrm{~cm})$, the lids were cut $(2 \times 2 \mathrm{~cm})$ and replaced by mesh cloth for aeration. The insect were reared in a controlled room $\left(26 \pm 1^{\circ} \mathrm{C}, 14: 10 \mathrm{LD}\right.$ and $\left.65 \pm 5 \% \mathrm{RH}\right)$ on an artificial diet (800 gm wheat, 160 gm yeast, $200 \mathrm{cc}$ glycerol and 200 cc natural honey) (Oberlander et al. 1978). A group of 10-day-old larvae were used for this study.

Pyriproxyfen (Admiral 10EC CNCCC.JS China ) was diluted in acetone and used in 0.02, 0.04, 0.08, 0.16 and $0.3 \mathrm{ppm}$ concentrations in the diet and a control with acetone was used for comparison in the diet. This experiment was replicated 8 times in a controlled room which was meant to provide as similar as possible the natural rearing conditions. In every experimental unit, $30 \mathrm{gm}$ of treated food with 10, ten-day-old larvae were used.

The percentage of adult emergence, and the duration of growth from the onset of the experiment till adult emergence, the adult longevity, the inhibition concentration $\left(\mathrm{IC}_{50}\right)$, the percentage of abnormal pupae, the oviposition rate and the hatchability percentage were recorded. When an adult emerged from different concentrations, the ovaries were removed from the cold-anesthetized insect under a dissecting microscope. The ovaries were homogenized in $1 \mathrm{ml}$ of Tris $50 \mathrm{mM}$ buffered at $\mathrm{pH} 7$.

Protein content was quantified according to the Bradford method (1976) using BSA as a standard. The absorbance was read at $630 \mathrm{~nm}$ in an eliza reader (Awareness
Technology INC USA). Three replicates were run for this analysis.

Lipid was extracted using the van Handel method (1965). Each dissected ovary was homogenized in $1 \mathrm{ml}$ of chloroform/methanol $(1: 1 \mathrm{v} / \mathrm{v})$. The homogenate was centrifuged at $10000 \mathrm{rpm}$ for $10 \mathrm{~min}$ at $4^{\circ} \mathrm{C}$. The aqueous part was discarded (repeated twice). The lipid extract was evaporated to dryness. The sample was digested with $1 \mathrm{ml}$ of sulphuric acid at $100^{\circ} \mathrm{C}$ for $10 \mathrm{~min}$. The tube was cooled and $5 \mathrm{ml}$ of sulphosphovanillin reagent (orthophosphoric acid/ $0.6 \%$ aqueous vanillin solution $4: 1$ ) was added to the mixture. After $40 \mathrm{~min}$, the absorbance was read at $530 \mathrm{~nm}$ and lipid level was calculated by a standard curve using cholesterol palmitate.

The comparisons of means were performed based on Tukey's test, in 5 percent estimation with SAS software (SAS 1997). IC I0 $_{50}$ was calculated by Polo-PC software (LeOra software 1987).

\section{RESULTS AND DISCUSSION}

The effect of pyriproxyfen on the developmental and biochemical parameters of $P$. interpunctella (Hübner) larvae are depicted in tables 1, 2, and 3. Based on these results, by increasing concentrations of pyriperoxyfen, the duration of the larval period till the emergence of adults were significantly increased compared to the controls $(p<0.0001)$. Increasing the concentrations, resulted in decreased adult longevity and significant reduction in mean eggs laid by adults compared to the controls ( $p<0.0001$ ) (Table 1). Development and reproduction in insects is affected by a number of hormones, including juvenile hormones (JHs). Williams (1967) proposed that timely application of JHs could be employed to control insects because of their ability to disrupt normal physiological functions. Insect growth regulators (IGRs) are synthetic mimics and analogues which mimic naturally occurring hormones and physiological processes of insects. Insect growth regulators are generally classified as $\mathrm{JH}$ analogues (JHAs), ecdysone agonists, or molt inhibitors (Mondal and Perween 2001). These synthetic mimics affect the normal development of immature insects (Mohandass et al. 2006). In the present investigation, pyriproxyfen, a juvenile hormone analogue, showed the potential for extending life stages which corresponds to the results of Edwards et al. (1995), Kellouche and Soltani (2006) and Sashindran et al. (2007). The prolongation of larval or pupal duration may be due to the persistence of $\mathrm{JH}$ in the hemolymph where it is only in the absence of $\mathrm{JH}$ that ecdyson could be activated and lead to the formation of the next stage (Kuwano et al. 2008). The prolongation or shortening of stage duration with IGRs, except chitin synthesis inhibitors, is due to the interference of these compounds on an endocrine source or inhibition of the release site of the prothoracicotropic hormone (PTTH) (Schmutter 1989; Subramanyam et al. 1989). In vitro and in vivo studies clearly showed that pyriproxyfen remarkably caused an inhibition of the ecdysone production thus interfering with normal development in Tenebrio molitor (Aribi et al. 2006).

There was no egg hatchability in all treatments compared to the control. Increasing the concentrations re- 
Table 1. Effects of pyriproxyfen on growth, longevity, fecundity and fertility of $P$. interpunctella (Hübner)

\begin{tabular}{|c|c|c|c|c|}
\hline Treatment [ppm] & Growth duration & Adult longevity [days] & Fecundity & Fertility \\
\hline Control & $13.97 \pm 0.10 \mathrm{f}$ & $8.81 \pm 0.11 \mathrm{a}$ & $294.7 \pm 2.38 \mathrm{a}$ & $98.67 \pm 0.33$ \\
\hline 0.02 & $16.23 \pm 0.10 \mathrm{e}$ & $7.3 \pm 0.11 \mathrm{~b}$ & $261.5 \pm 2.38 \mathrm{~b}$ & 0.00 \\
\hline 0.04 & $18.18 \pm 0.10 \mathrm{e}$ & $7.2 \pm 0.11 \mathrm{~b}$ & $107.9 \pm 2.38 \mathrm{c}$ & 0.00 \\
\hline 0.08 & $19.21 \pm 0.10 \mathrm{c}$ & $6.17 \pm 0.11 \mathrm{c}$ & $101.2 \pm 2.38 \mathrm{c}$ & 0.00 \\
\hline 0.16 & $22.28 \pm 0.10 \mathrm{~b}$ & $5.18 \pm 0.11 \mathrm{~d}$ & $73.4 \pm 2.38 \mathrm{~d}$ & 0.00 \\
\hline 0.3 & $25.63 \pm 0.10 \mathrm{a}$ & $3.57 \pm 0.11 \mathrm{e}$ & $47.8 \pm 2.38 \mathrm{e}$ & \\
\hline
\end{tabular}

Means within column followed by different letters indicate significant differences $(\mathrm{p}<0.0001)$

Table 2. Effect of pyriproxyfen on the percent of adult emergence and on the percentage of abnormal pupae after treatment of 10-day-old larvae of $P$. interpunctella (Hübner)

\begin{tabular}{|c|c|c|c|}
\hline Treatment [ppm] & $\begin{array}{c}\text { Total percentage of } \\
\text { emerged adults }\end{array}$ & $\begin{array}{c}\text { Percentage of } \\
\text { abnormal adults }\end{array}$ & $\begin{array}{c}\text { Percentage of } \\
\text { abnormal pupae }\end{array}$ \\
\hline Control & $96.25 \pm 2.32 \mathrm{a}$ & $0.0 \pm 2.85 \mathrm{c}$ & $0.0 \pm 2.20 \mathrm{~d}$ \\
\hline 0.02 & $93.75 \pm 2.32 \mathrm{a}$ & $6.25 \pm 2.85 \mathrm{bc} \pm 2.20 \mathrm{~d}$ \\
\hline 0.04 & $71.25 \pm 2.32 \mathrm{~b}$ & $10 \pm 2.85 \mathrm{~b}$ & $32.75 \pm 2.20 \mathrm{c} \pm 2.20 \mathrm{c}$ \\
\hline 0.08 & $67.5 \pm 2.32 \mathrm{~b}$ & $12.5 \pm 2.85 \mathrm{a}$ & $50 \pm 2.32 \mathrm{c}$ \\
\hline 0.16 & $50 \pm 2.32 \mathrm{c}$ & $20 \pm 2.85 \mathrm{a}$ & $80 \pm 2.20 \mathrm{a}$ \\
\hline 0.3 & $20 \pm 2.32 \mathrm{~d}$ & $10 \pm 2.85 \mathrm{~b}$ & 32.5 \\
\hline
\end{tabular}

Means within column followed by different letters indicate significant differences $(\mathrm{p}<0.0001)$

Table 3. Effect of pyriproxyfen on lipid and protein content of the ovaries in adults emerging from 10-day-old treated larvae of $P$. interpunctella (Hübner)

\begin{tabular}{|c|c|c|}
\hline Treatment [ppm] & Total protein [mg/ovary] & Total lipid [mg/ovary] \\
\hline Control & $4.48 \pm 0.07 \mathrm{a}$ & $371.45 \pm 14.5 \mathrm{a}$ \\
\hline 0.02 & $3.08 \pm 0.07 \mathrm{~b}$ & $330.93 \pm 14.5 \mathrm{a}$ \\
\hline 0.04 & $1.96 \pm 0.07 \mathrm{c}$ & $96.33 \pm 14.5 \mathrm{~b}$ \\
\hline 0.08 & $1.84 \pm 0.07 \mathrm{c}$ & $71.68 \pm 14.5 \mathrm{~b}$ \\
\hline 0.16 & $1.28 \pm 0.07 \mathrm{~d}$ & $5.67 \pm 14.5 \mathrm{c}$ \\
\hline 0.3 & $1.2 \pm 0.07 \mathrm{~d}$ & - \\
\hline
\end{tabular}

Means within column followed by different letters indicate significant differences $(\mathrm{p}<0.0001)$

Table 4. IC $\mathrm{IC}_{50}$ values and confidence limit (95\%) and slope of pyriproxyfen treatment of 10-day-old larvae

\begin{tabular}{|c|c|c|c|c|}
\hline Compound & No. of insects & Slope \pm SE & GL 95\% & $\mathrm{IC}_{50}[\mathrm{ppm}]$ \\
\hline Pyriperoxyfen & 480 & 1.0 .22 & $0.067-0.305$ & 0.134 \\
\hline
\end{tabular}




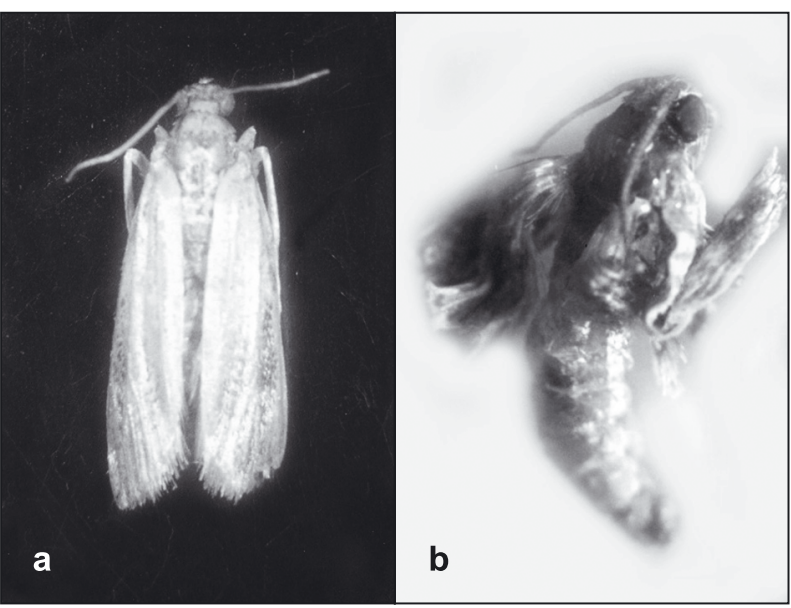

Fig. 1. Normal adult (a) and abnormal adult with twisted wings (b) $(450 \mathrm{X})$

sulted in low emergence of normal adults so that some adultoids were emerged from treated larvae which was more pronounced in $0.16 \mathrm{ppm}$ concentration. These adultoids showed abnormal legs and twisted wings thus, the adults were unable to move their legs and wings (Fig. 1). The current study demonstrated that the longevity of the adults emerging from treated larvae was significantly reduced compared to the control. The result corresponded to those reported for Lipaphis orsini (Liu and Chen 2001), Thrips tabaci (Thysanoptera: Thripidae) (Liu 2003) and Bicyclus anyana (Steigenga et al. 2006). The percent of emerged adults from the larval treatment was reduced which was similar to the results of Richardson and Lagos (2007) on Aphis glycines (Heteroptera: Aphididae) and Arthur (2004) on Rhyzopertha dominica (Coleoptera: Bostrichidae). Pyriproxyfen treatment made significant changes in external morphology of resultant pupae and emerged adults which is similar to the results of Hussein et al. (2005) and Arthur (2004) on Tribolium castaneum and T. confusum and Aribi et al. (2006) on Tenebrio molitor. In the pupal period, $\mathrm{JH}$ is not produced by the insects and only ecdyson is produced (Chapman 1998). Therefore, by the addition of external JHA during the larval period the insect is unable to exude excess JH. For this reason, the presence of JHA may lead to inhibition of ecdysone production therefore leading to discrepancy in later development as was shown in T. molitor (Aribi et al. 2006).

The inhibition concentration was calculated to be 0.134 which could inhibit 50 percent of adult emergence (Table 4). Treated larvae led to pupa like pupoids or larval like larvoids and the maximum effect was observed in the 0.3 ppm treatment ( $80 \pm 2.20$ percent) (Fig. 2).

When dissecting the adultoids a significant reduction in ovaries was observed (Fig. 3a-f). Total protein and lipids showed significant reduction compared to the controls in various treatments so that their amounts decreased between 4-300-fold compared with the control (Table 3). The result corresponded to the results obtained by Perween and Miyata (2000) on Spodoptera litura, Kelluche and Soltani (2006) on Callosobruchus maculatus, Hami et al. (2004) on Tenebrio molitor. Shekari et al. (2008) found similar results after treatment of Xanthogaleruca lu-

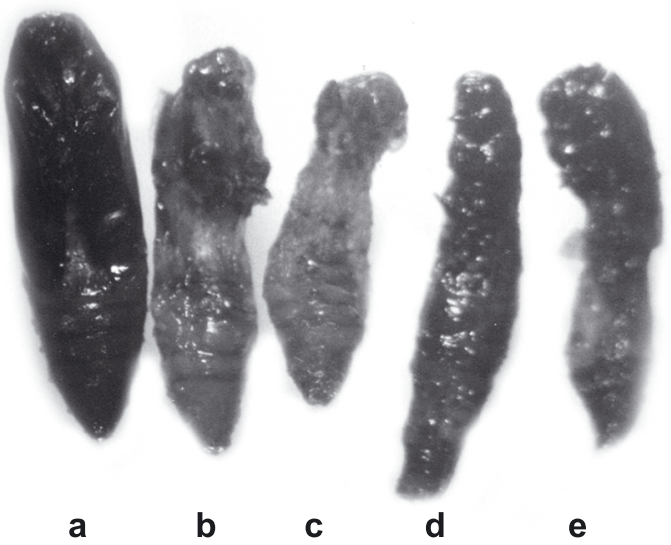

Fig. 2. Normal pupa (a) and different morphological abnormalities in treated larvae $(b-e)$

teola larvae with a plant extract. One of the main reasons for reduction in ovarian size in treated insects by $\mathrm{JH}, \mathrm{JHA}$, or growth regulator of plant origin, is the lack of materials supplied through hemolymph to the growing ovaries (Telfer et al. 1981) or due to the lack of materials made by the ovaries themselves (Indrasith et al. 1988). The lack of compounds like proteins, lipids, and carbohydrates may lead to abnormal oogenesis (Kunkel and Nordin 1985; Kanost et al. 1990). The decrease of two major biochemical compounds: lipid and protein, in the ovaries of the present insect may confirm this assumption. Shaya et al. (1993) reported that the growth of ovaries in P. interpunctella in early pupa is under the influence of high titer of ecdysone in hemolymph but vitellogenesis is under the influence of low titer of ecdysone. Hence, another reason for the low rate of growth in the ovaries of the present insect may be due to a discrepancy in ecdysone production in the presence of excess JHA after larval treatment. We found that incorporation of pyriproxyfen had a direct role on fecundity and fertility of treated insects, therefore it may be concluded that this compound had an effect on the growth of ovaries and oogenesis. Reduction in fecundity has been reported by Richardson and Lagos (2007) on Aphis glycines and Chanhang et al. (2008) on Rhyzopertha dominica. The results of Perween and Miyata (2000) showed that topical incorporation of Chlorfluazuron on ultimate instar larva of $S$. litura reduced the fecundity and fertility of adults. They speculated that reduced ovarian growth and oogenesis is responsible for reduced fecundity. The same reason might be the cause of the reduced fecundity and fertility in the studied insect. In the present investigation, it became clear that the lipids and proteins of ovaries in treated insects were reduced compared to the controls. These findings correspond to the results obtained by Perveen and Miyata (2000) where protein content in treated S. litura by Chlorfluazuron in ovaries was reduced. They speculated that the reduction of protein in the ovaries may be due to interruption of the compound with controlling mechanisms in yolk incorporation. Total protein and lipid in P. interpunctella in whole larva was similarly reduced by 20-hydroxyecdysone and azadirachtin (Rharrabe et al. 2008). They concluded that the 

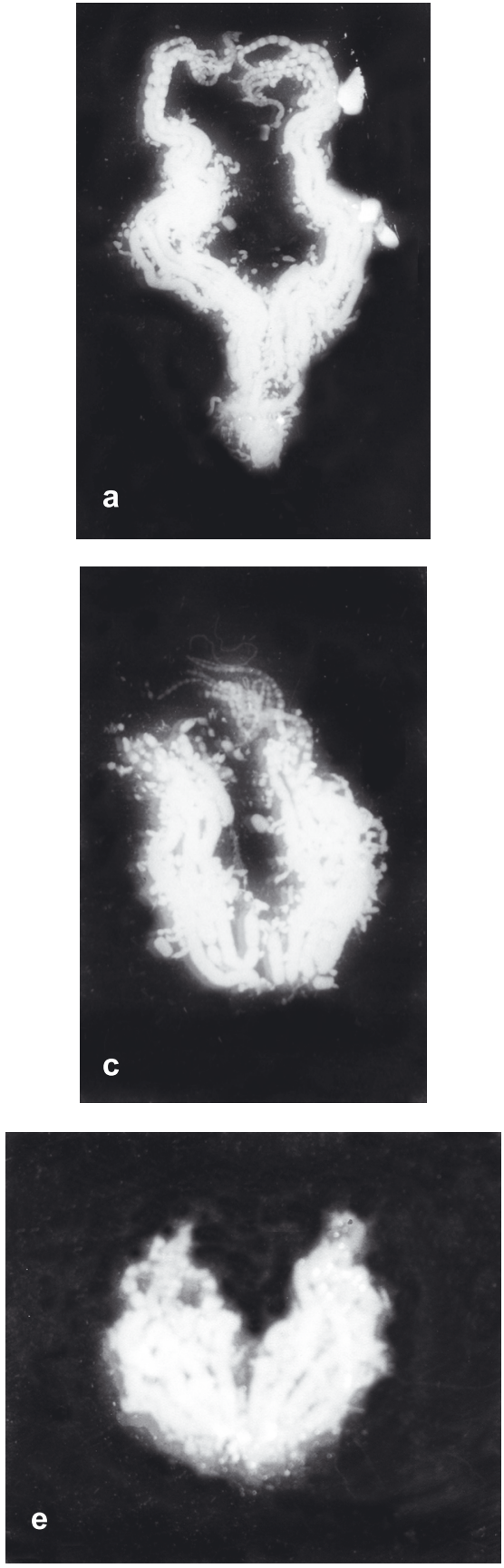
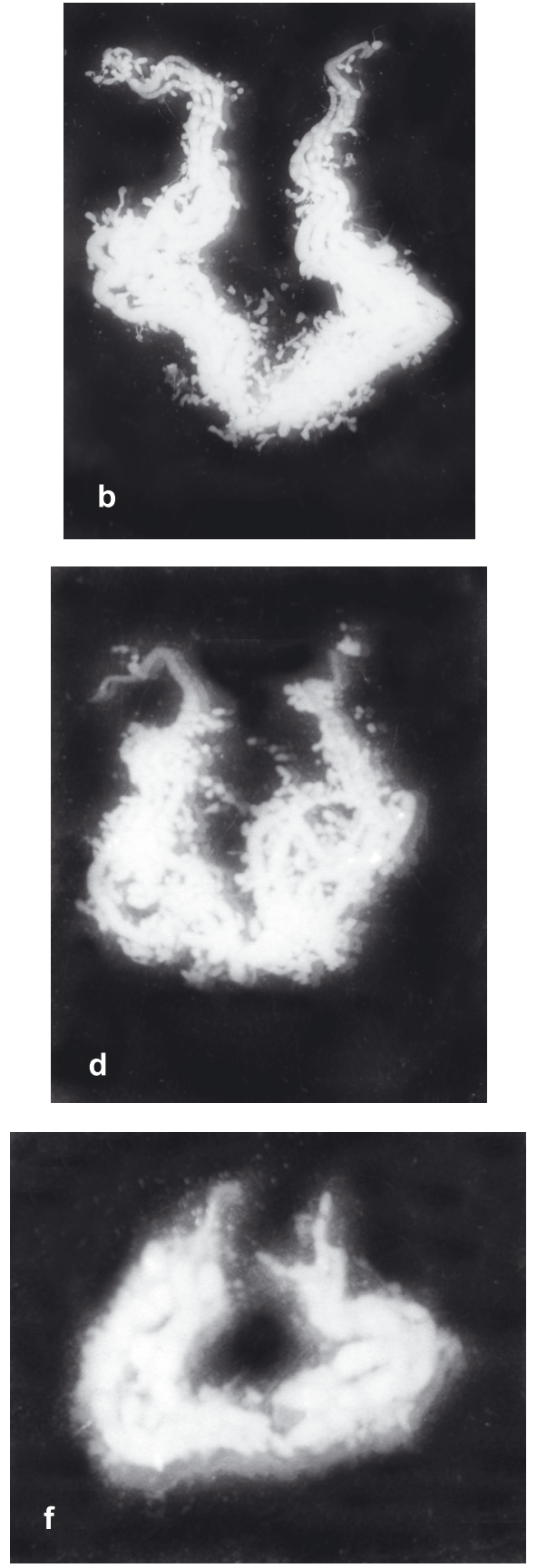

Fig. 3. Various developmental abnormalities in ovaries of treated (b-f) vs. the control (a), 0.02 ppm JHA (b), 0.04 ppm (c), 0.08 ppm (d), 016 ppm (e) and 0.3 ppm (f) (600 X)

depletion of these biochemical constituents could be due to major mobilization of these substances in response to the midgut as well as reduction of their synthesis.

In the future we can expect additional development and more advanced final adjustment of the insecticides and application techniques. We can also expect to obtain new knowledge about physical-chemical properties that determine the destiny of the insecticides in the environment and in biological systems (Zibaee et al. 2009). In this study, it is almost clear that pyriproxyfen mimics the action or natural $\mathrm{JH}$ and maintains the insect in an immature state. This action keeps the insects from molting successfully or reproducing normally. It is one of the insecti- cides recommended by $\mathrm{WHO}$ as an addition to drinking water for public health purposes (Sullivan and Goh 2008). Hence, we believe that its incorporation in food commodities for controlling stored product pests are appreciated.

\section{ACKNOWLEDGEMENTS}

The authors would like to thank the University of Guilan's research office for the financial support for our project. We also thank Aidin Zibaee for his technical help. 


\section{REFERENCES}

Abdallah M.D., Zaazou M.H., Tantawi M.E. 1975. Reduction in fecundity and hatchability after exposure of pupae and eggs of Spodoptera littoralis (Boisd.) to juvenile hormone and analogues. Z. Angew. Entomol. 78 (1-4): 176-181.

Arias J.R., Mulla M.S. 1975. Morphogenetic aberrations induced by a juvenile hormone analogue in the mosquito, Culex tarsalis (Diptera: Culicidae). J. Med. Entomol. 12 (3): 309-316.

Aribi N., Smagghe G., Lakbar S., Soltani-Mazouni N., Soltani N. 2006. Effects of pyriperoxyfen, a juvenile hormone ana$\log$, on development of the mealworm, Tenebrio molitor. Pestic. Biochem. Physiol. 84 (1): 55-62.

Arthur F.H. 2003. Efficacy of a volatile formulation of hydroprene (pointsource ${ }^{\mathrm{TM}}$ ) to control Tribolium castaneum and Tribolium confusum (Coleoptera: Tenebrionidae). J. Stored Products Res. 39: 205-212.

Arthur F.H. 2004. Evaluation of methoprene alone and in combination with diatomaceous earth to control Rhyzopertha dominica (Coleoptera: Bostrichidae) on stored wheat. J. Stored Products Res. 40: 485-498.

Bradford M.M. 1976. A rapid and sensitive method for the quantiation of microgram quantities of protein-dye binding. Anal. Biochem. 72: 248-254.

Carter S.W. 1975. Laboratory evaluation of three novel insecticides inhibiting cuticle formation against some susceptible and resistant stored product beetles. J. Stored Products Res. 11: 187-193.

Chanbang Y., Arthur F.H., Wilde G.E., Throne J.E., Subramanyam B.H. 2008. Susceptibility of eggs and adult fecundity of the lesser grain borer, Rhyzopertha dominica, exposed to methoprene. J. Insect Sci. 8: 1-5.

Chapman R.F. 1998. The Insects Structure and Function. Cambridge University Press, New York, 750 pp.

Cox P.D., Bell C.H. 1991. Biology and ecology of moth pests on stored food. p. 181-193. In: "Ecology and Management of Food-Industry Pests" (J.R. Gorham, ed.). Association of Official Analytical Chemists, Arlington, VA.

Edwards J.P., Corbit H.F., McArdle J.E., Short J.E., Weaver R.J. 1995. Elimination of population of the oriental cockroach (Dictyoptera: Blatellidae) in a simulated domestic environment with the insect juvenile hormone analogue (S)-hydroprene. J. Econ. Entomol. 86: 436-443.

Hami M., Taibi F., Soltani-Mazouni N. 2004. Effects of flucycloxuron, chitin synthesis inhibitor on reproductive events and thickness of chorion in mealworms. Commun. Agric. Appl. Biol. Sci. 69 (3): 249-255.

Hussein H.M., Dimerty N., Zidan Z., Iss-hak R.R., Sehnal F. 2005. Effect of insect growth regulators on hairy horse beetle, Tropinota squalida (Coleoptera: Scarabaeidae). J. Appl. Entomol. 129: 142-148.

Indrasith L.S., Sasaki T., Yaginuma T., Yamashita O. 1988. The occurrence of premature form of egg-spesific protein in vitellogenic follicles of Bombyx mori. J. Comp. Physiol. 158 (1): $1-7$.

Ishaaya I., Horowitz R. 1995. Pyriproxyfen, a novel insect growth regulator for controlling whiteflies. Mechanism and resistance management. Pestic. Sci. 43 (3): 227-232.

Ishaaya I., Horwitz A.R. 1998. Insecticides with novel modes of action: an overview. p. 1-24. In: "Insecticides with Novel Modes of Action: Mechanisms and Application" (I. Ishaaya, D. Degheele, eds.). Springer, Berlin, 24 pp.
Ishaaya I., Yablonski S., Ascher K.R.S. 1987. Toxicological and biochemical aspects of novel Acylureas on resistant and susceptible strains of Tribolium castaneum. p. 613-622. In: Conference on Stored- Product Protection. Tel Aviv, Israeel, 21-26 September 1986.

Kanost M.R., Kawooya J.K., Law J.H., Ryan R.O., van Heusden M.C., Ziegler R. 1990. Insects haemolymph proteins. Adv. Insect Physiol. 22: 299-396.

Kellouche A., Soltani N. 2006. Impact of hexaflumuron, a chitin synthesis inhibitor, on growth, development and reproductive performance of the progeny in Callosobruchus maculatus after adult treatments. Afr. J. Agric. Res. 1 (3): 57-64.

Kim K., Kim Y. 2002. A biochemical evidence of the inhibitory effect of diflubenzuron on the metamorphosis of the silkworm, Bombyx mori. J. Asian-Pacific Entomol. 5 (2): 175-180.

Kostyukovsky M.B., Chen A.S., Shaaya E. 2000. Biological activity of two juvenoids and ecdysteroids against three stored product insects. Insect Biochem. Molec. 30 (8-9): 891-897.

Kunkel J.G., Nordin J.H. 1985. Yolk protein. p. 83-112. In: “Comparative Insect Biochemistry, Physiology, and Pharmacology", Vol.1. (G.A. Kerkut, L.I. Gilbert, eds.). Pergamon, Oxford.

Kuwano E., Fujita N., Furuta K., Yamada N. 2008. Synthesis and biological activity of novel anti-juvenile hormone agents. J. Pestic. Sci. 33 (1): 14-16

Leonardi M.G., Marciani P., Montorfono P.G., Cappellozza S., Giordana B., Monticalli G. 2001. Effects of fenoxycarb on leucine uptake and lipid composition of midgut brush border membrane in the silkworm, Bombyx mori (Lepidoptera: Bombycidae). Pestic. Biochem. Physiol. 70 (1): 42-51.

LeOra Software 1987. Polo-Pc: A User Guide to Probit or Logit Analysis. LeOra software, Berkeley, California, 22 pp.

Liu T.X. 2003. Effects of pyriproxyfen on onion thrips. Pestic. Manage. Sci. 59 (8): 904-912.

Liu T.X., Chen T.Y. 2001. Effects of a juvenile hormone analog, pyriproxyfen, on the apterus form of Lipaphis erysimi. Entomol. Exp. Appl. 98: 295-301.

Maiza A., Kilani S., Fraine J.P., Aribi N., Soltani N. 2004. Reproductive effects in German cockroach by ecdysteroid agonist RH- 0345, juvenile hormone analogue methoprene and carbamate benfuracarb. Commun. Agric. Appl. Biol. Sci. 69 (3): 257-266.

Metwally M.M., Sehnal F., Landa V. 1972. Reduction of fecundity and control of khapra beetle by juvenile hormone mimics. J. Econ. Entomol. 65: 1603-1605.

Miyamoto J., Hirano M., Takimoto Y., Hatakoshi M. 1993. Insect growth regulators for pest control, with emphasis on juvenile hormone analogs: present and future prospects. p. 144-168. In: "Pest Control with Enhanced Environmental Safety" (S.O. Duke, J.J. Menn, J.R. Plimmer, eds.). Washington D.C., ACS Symp. Ser. Vol. 524.

Mohandass S.M., Arthur F.H., Zhu K.Y., Throne J.E. 2006. Hydroprene: mode of action, current status in stored-product pest management, insect resistance, and future prospects. Crop Protect. 9: 902-909.

Mondal K.A., Parween S. 2000. Insect growth regulators and their potential in the management of stored-product insect pests. Integr. Pest Manage. Rev. 5 (4): 255-295.

Nino E.L., Sorenson C.E., Washburn S.P., Watson D.W. 2009. Effects of the insect growth regulator, methoprene, on $\mathrm{On}$ thophagus taurus (Coleoptera: Scarabaeidae). Environ. Entomol. 38 (2): 493-498. 
Oberlander H., Nickle D., Silhacek D.L., Hagstrum D.W. 1978. Advances in insect growth regulators research with grain insects. p. 247-263. In: Symposium on the Prevention and Control of Insects in Stored Foods Products. Manhattan Kansas 1987.

Oberlander H., Silhacek D.L., Shaaya E., Ishaaya I. 1979. Current status and future perspective of the use of insect growth regulators for the control of stored product insects. J. Stored Product Res. 33 (1): 1-6.

Paoletti M.G., Pimental D. 2000. Environmental risks of pesticides versus genetic engineering for agricultural pest control. J. Agric. Environ. Ethics 12 (3): 279-303.

Pedigo L.P. 2002. Entomology and Pest Management. Prentice Hall, Upper Saddle River, N.J., 691 pp.

Perveen F., Miyata T. 2000. Effects of sub lethal dose of chlorfluazuron on ovarian development and oogenesis in the common cutworm Spodoptera litura (Lepidoptera: Noctuidae). Ann. Entomol. Soc. Am. 93 (5): 1131-1137.

Retnakaran A. 1970. Blocking of embryonic development in the spruce budworm, Choristoneura fumiferana (Lepidoptera: Tortricidae), by some compounds with juvenile hormone activity. Can. Entomol. 102: 1592-1596.

Rharrabe K., Amri H., Bouayad B., Sayah F. 2008. Effects of azadirachtin on post-embryonic development, energy reserves and $\alpha$-amylase activity of Plodia interpunctella Hübner (Lepidoptera: Pyralidae). J. Stored Products Res. 44 (3): 290-294.

Richardson M.L., Lagos D.M. 2007. Effects of a juvenile hormone analogue, pyriproxyfen, on the apterus form of soybean aphid (Aphis glycines). J. Appl. Entomol. 131: 297-302.

Rumpf S., Frampton C., Dietrich D.R. 1998. Effects of conventional insecticides and insect growth regulators on fecundity and other life-table parameters of Micromus tasmaniae (Neuroptera: Hemerobiidae). J. Econ. Entomol. 91: 34-40.

SAS Institute 1997. SAS/STAT User's Guide for Personal Computers SASInstitute, Cary, NC.

Sashindran Nair K., Sashindran Nair J., Vijayan V.A. 2007. Alteration in the primary metabolites in three different tissues of silkworm, Bombyx mori L. under the influence of a juvenoid, R394. Casp. J. Environ. Sci. 5 (1): 27-33.

Schmutterer H. 1989. Potential of azadirachtin - containing pesticides for integrated pest control in developing and industrialized countries. J. Insect Physiol. 34 (7): 713-719.

Shaaya E., Shirk R.D., Zimowska G., Plotkin S., Young N.J., Rees H.H., Silhacek D.L. 1993. Declining ecdysteroid levels are temporally correlated with the initiation of vitellogenesis during phareate adult development in Indian meal moth, Plodia interpunctella. Insect Biochem. Mol. Biol. 23 (1): 153-158.

Shekari M., Jalali Sendi J., Etebari K., Zibaee A., Shadparvar A. 2008. Effects of Artemisia annua L. (Asteracea) on nutritional physiologyand enzyme activities of elm leaf beetle, Xanthogaleruca luteola Mull. (Coleoptera: Chrysomelidae). Pestic. Biochem. Physiol. 91 (1): 66-74.

Staal G.B. 1975. Insect growth regulators with juvenile hormone activity. Annu. Rev. Entomol. 20: 417- 460

Steigenga M.J., Hoffmann K.H., Fischer K. 2006. Effects of the juvenile hormone mimic pyriproxyfen on female reproduction and longevity in the butterfly Bicyclus anynana. Entomol. Sci. 9 (3): 269-279.

Subrahmanyam B., Muller T., Rembold H. 1989. Inhibition of turnover of neurosecretion by azadirachtin in Locusta migratoria. J. Insect Physiol. 35: 493-500
Sullivan J.J., Goh K.S. 2008. Environmental fate and properties of pyriproxyfen. J. Pestic. Sci. 33: 339-350.

Telfer W.H., Rubenstein E., Pan M.L. 1981. Regulation of Insect Development and Behaviour. Technical University Press, Wroclaw.

van Handel E., 1965. Micro-separation of glycogen, sugars and lipids. Anal. Biochem. 11 (2): 266-271

Williams P., Amos T.G. 1974. Some aspects of synthetic juvenile hormones and hormone analogues on Tribolium castaneum (Herbst.). Aust. J. Zool. 22 (2): 142-153.

Williams C.M. 1967. Third generation pesticides. Am. J. Sci. 217: 13-17.

WMO 1994. Scientific assessment of ozone depletion. In: Proc. World Meterological Organization Global Ozone Research and Monitoring Project. Report N. 37. WMO, Geneva.

Zibaee A., Bandani A.R. 2009. Effect of five different pesticides on the Sunn pest, Eurygaster integriceps. Munis. Entomol. Zool. 4: 470-478

Zurfleuh R.C. 1976. Phenyl ethers as insect growth regulators: laboratory and field experiments. p. 61-74. In: "The Juvenile Hormones" (L.I. Gilbert, ed.). Plenum Press, New York.

\section{POLISH SUMMARY}

\section{WPŁYW PYRIPROXYFENU NA ZMIANY FIZJOLOGICZNE I BIOCHEMICZNE W MOLU MĄCZNYM PLODIA INTERPUNCTELLA (HÜBNER) (LEPIDOPTERA: PYRALIDAE)}

Regulatory wzrostu owadów zwykle mają selektywne działanie na docelowe owady i praktycznie nie mają oczywistego działania ubocznego na organizmy niedocelowe, zwłaszcza kręgowce. Regulatory wzrostu mogą nadawać się odpowiednio do zwalczania szkodników w magazynowanych produktach. Dziesięciodniowe larwy indyjskiego mola mącznego Plodia interpunctella Hübner, były eksponowane na działanie analoga hormonu młodocianych stadiów pyriproxyfenu w celu uzyskania działania na wzrost, metamorfozę, reprodukcję, zawartość lipidów i białka w jajnikach. Larwy traktowano hormonem (IHA) obecnym w sztucznej diecie, a osobniki kontrolne otrzymywały w diecie sam aceton. Wyniki wskazywały na istotne różnice $\mathrm{w}$ trwaniu wzrostu, w średnim okresie trwania wylęgłych osobników dorosłych, w procesie wylęgłych normalnych osobników dorosłych, nienormalnych poczwarek, wylęgłych larw i w średnim tempie składanie jaj, w dodatku do lipidów i białka w jajnikach, w porównaniu do kontroli. Stężenie wywołujące inhibicję o wartości 50 (IF50) dla zapobieżenia wylęgu osobników dorosłych wynosiło 0,134 ppm. Pyriproxyfen powodował istotne defekty w nogach i skrzydłach niektórych osobników dorosłych, i duże zmiany morfologiczne w jajnikach wylęgłych dorosłych. Wyniki wykazały, że pyriproxyfen może być stosowany jako insektycyd w celu zmniejszenia szkód wywołanych przez indyjskiego mola mącznego w magazynowanych produktach. Pyriproxyfen może być używany, wywołując niskie efekty uboczne w stosunku do ludzi. 